\title{
5 \\ Female Difficulties, Comparativist Challenge: Novels by English and German Women, 1752-1814
}

\author{
CHRIS Cullens
}

Comparative literature is an academic field which, in spite of its interdisciplinary structure, still tends to reinforce traditional literaryhistorical schemas of periodization, canon formation, and genre. What comparativists define themselves as "doing" in their dissertations, books, and course descriptions still often seems to receive its institutional legitimation by reference to one of those traditional categories, to a collection of major figures, or to a recognized pattern of crossnational literary influence or "history of ideas" paradigm.

This can make it difficult to find a niche for cross-national approaches to women's social history, noncanonical women writers, or indeed to any type of literature labeled "popular" or "mass." It may have become possible now to write or teach on "comparative topics such as George Eliot and George Sand, or on major twentieth-century women writers from Virginia Woolf to Christa Wolf; it is even possible, for instance, to work on a whole group of "minor" female authors writing within one genre and one national literature. But if one wants to devote time to a field such as the letters, journals, and household accounts of seventeenth- and eighteenth-century German, French, and English women, or North and South American women's magazine fiction, the institutional framework and audience for such an undertaking remains more limited. This type of research is necessary if feminist literary studies within the university are to fulfill their potential for questioning the very definition of "literature," and are not to end up revolving around yet another (female) "major works by major authors" canon. Yet such feminist comparative studies are further impeded by the sheer mass of background and historical material relating to two or more national

A version of this essay appears in my book "Female Difficulties": Novels by English and German Women, 1752-1814 forthcoming from Stanford University Press and is reprinted here by permission. 
cultures which must be mastered, and by the problems of rare or untranslated sources.

My examination of the work of English and German female novelists writing between approximately 1750 and 1810 has led me to conclude that standard paradigms of literary periodization, canonization, and form do not always offer helpful guidelines for defining the special characteristics and role of this fiction within the framework of a comparative analysis. In the last decades of the eighteenth century the novel did undeniably consolidate its hold on the literary market; in turn, the form's popularity, and specifically the subgenre of the epistolary novel, gave writing women their best opportunity so far to gain some modicum of authorial credibility within the English and German publishing industries. ${ }^{1}$ But how does one account for the contributions of these female novelists to the novel's "rise" and dominance within an interEuropean or cross-national context?

A starting point is provided by the basic fact that women novelists writing in these two languages during this era used much the same range of subgenres and plots, and produced structurally and tonally similar works. This similarity cannot, however, be conveniently explained by direct contact (few German women ever had the chance to visit England, or vice versa). Biographical evidence rarely permits generalizations about what English and German women could have been absorbing from translations, or sources such as review journals, correspondence, or personal acquaintance, of one anothers' literature. In addition, these commonalities among women writers are not accounted for by the standard demarcations of literary periods or schools, such as neoclassicism, the Age of Johnson, the Enlightenment, Sturm und Drang, and various Romanticisms. In England, between the death of Smollett in 1771 and the 1790 os, fictional subgenres became so fluid and syncretic that even traditional literary scholarship has approached those two decades as a kind of canonical interregnum, to which designations such as the Age of Sensibility do limited justice. By contrast, in German studies, literature of these decades tends to get measured against the two big categories of classicism and Romanticism. But, as Jeannine Blackwell summarizes the resulting "methodological hindrances": "At a time of unique and prolific novel publication and salon activity, women's lit-

'See Jane Spencer, The Rise of the Woman Novelist: From Aphra Behn to Jane Austen (Oxford: Basil Blackwell, 1986); Silvia Bovenschen, Die imaginierte Weiblichkeit: Exemplarische Untersuchungen zur kulturgeschichtlichen und literarischen Präsentationsformen des Weiblichen (Frankfurt am Main: Fischer, 1979); and Nancy Miller, The Heroine's Text: Readings in the French and English Novel, 1722-1782 (New York: Columbia University Press, 1980). 
erary lives fit into neither frame. Women did not write Romantic novels or poetry-they wrote Gesellschaftsromane, Erziehungsromane, described Frauenideale, and organized literary intercourse in the semipublic sphere of the salon.... Women, with a different literary tradition and different cultural role expectations, were simply marching to a different drummer." ${ }^{\prime 2}$

Indeed, Romanticism's "high argument" manifested itself as an aesthetic ideology steered by an overtly masculinized image of the artist. This tended to exclude female writers of narrative fiction from the sphere of "high art," and hence exercised little pull on them, at least until the Brontës. ${ }^{3}$ (The one major exception was probably Madame de Staël.) As a result, women publishing novels in the late eighteenth century by and large did not court identification with, or advertise a polemical adherence to, contemporary literary movements. Writing at the level of popular rather than pointedly innovative fiction, the majority of these female novelists based their appeal and their claim to authorial credibility on their depictions of the ubiquitous dilemmas of domestic life, their flexible reworkings of tried-and-true plot paradigms and character constellations, and a narratorial stance that combined "sympathetic" portrayal with purportedly conservative moral guidance. Consequently, no simple rubic (even "sentimentalism," capacious as that term is) can cover the works of these female novelists.

Instead of trying to slot such authors into existing paradigms of period and influence, it is more valuable to examine their works in terms of the conditions of production within which they operated. First, similar social-historical conditions governed the whole sphere of education, Bildung, and literacy for English and German women, dictating their approach to writing and reading fiction. Second, similar market conditions in England and Germany enabled women to claim a limited writerly authority as popular novelists, as they drew on an interEuropean literary subtradition of popular fiction which continued to flourish apart from "high culture" aesthetic innovations. Third, female novelists were to a large extent shut out from participating in the institutions, public opportunities, and collective undertakings that shaped and bonded the sensibilities of male novelists (the university years, especially important in Germany; the "Grand Tour" and possibility of

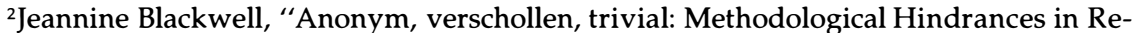
searching German Women's Literature," Women in German Yearbook 1 (1985): 39-59, 4647 .

${ }^{3}$ See M. H. Abrams, Natural Supernaturalism: Tradition and Revolution in Romantic Literature (New York: Norton, 1971), 17-70; and Margaret Homans, Women Writers and Poetic Identity (Princeton: Princeton University Press, 1980).
} 
extended, unsupervised travel; the editorship of literary periodicals; and so on). Women instead found their training ground in the related activities of letter writing and journal keeping, benefiting from an unsystematic "home" education in which (as pedagogical moralists ceaselessly warned) the reading of novels and romances themselves seemed to have played a suspiciously large role. Indeed, when female novelists in both languages write about female characters, they recur to the issue of how textual consumption and production by women can both discipline and destabilize proper notions of femininity and domesticity.

The English writer Frances Burney titled her last novel, published in 1814, The Wanderer, or Female Difficulties. Burney's novel represents a culmination of an eighteenth-century tradition of feminocentric fiction; hence, it is logical that its subtitle should announce the work's intention to deal programmatically with the wide spectrum of complications attendant on female existence, when it is defined in terms of a rather narrow range of socially acceptable options. The fictions of Burney and her less well known English and German female contemporaries all reflect on specifically female difficulties, the omnipresent limitations imposed by eighteenth-century standards of correct feminine behavior and self-presentation. Likewise, this fiction reflects structurally the efforts of female writers to cope with the difficulties of assuming literary authority under conditions of production which subjected them to a special set of external and internalized constraints. Women who wrote during this period knew they had to "watch themselves," in every sense: they focused intensely on the specular and psychological dynamics of being an object of monitory surveillance. These writers made the imperative to "watch yourself" into a byword, as their heroines also ceaselessly watch themselves textually-in interpolated journals, letters, and confessional accounts-even as they watch themselves being watched by others around them. The torment unleashed by this internalized mandate is one of the difficulties that leave their mark on eighteenth-century novels by women, while the pleasures and the narcissistic gratification that imperative legitimates, however deviously, constitute a productive side effect of the same set of difficulties.

The resulting self-conscious, ambivalent awareness of their own crucial and vulnerable role in the "encouragement" of proper female readers and their oblique, partial assumption of full aesthetic authority thus shaped the works of female novelists during this era regardless of the language and novelistic subgenre (gothic novel, historical novel, Tendenzroman, courtship or marriage plot) they were employing, whether they were writing in 1770 or 1814 , or under the ostensible influence of Richardson, Rousseau, Goethe, rationalism, sentimentalism, or Roman- 
ticism. What makes this particular body of novels so interesting is precisely that all these subgenres, influences, and modes became amalgamated within that matrix of popular fiction which female novelists claimed as their own territory. This amalgamation calls for some qualification of the suggestion that female writers of the era were marching to a single different drummer, however ubiquitous the female difficulties they confronted may have been, and productively complicates any monolithic conceptualization of both "tradition" and "countertradition." If that, in turn, makes it difficult to approach fiction produced by women in both languages during this period in terms of the linear, isolated national evolution of one genre, period, or school, then maybe we should view this as an encouragement to look at what defines the cross-national continuity of late eighteenth-century women's fiction first and foremost in terms of the singularities of the works themselves, and the social-historical conditions and transformations that made them possible.

In late 1796 literary Germany was abuzz with curiosity about the author of a new novel, which had appeared in installments in Schiller's periodical Der Horen. The work, Agnes von Lilien, appeared anonymously, and Schiller zealously guarded the secret of its authorship, leading some people to suspect that he was the author. Other readers credited it to Goethe, since the new novel bore some resemblance to Wilhelm Meister, even though its eponymous protagonist was female. Neither Schiller nor Goethe was flattered by this attribution, in spite of the novel's popularity, although Schiller at least derived a malicious pleasure from watching the Schlegel circle lead the way in proclaiming Goethe's authorship; Caroline Schlegel reportedly even praised Goethe for achieving a new height in the representation of female character. By mid-1797, however, the name behind this overnight literary success was out: it belonged to Schiller's sister-in-law, Caroline von Wolzogen, a lady known up to this point less for her literary efforts than for her divorce. After three editions between 1798 and 180o, the novel and its author largely disappeared from the public eye, Agnes von Lilien being remembered as a charming minor work and Wolzogen for her relation to, and memoir of, her eminent brother-in-law. Nonetheless, German literary historians, inasmuch as they have accorded the novel any attention, generally persisted in identifying it with Goethe by categorizing it as a Wilhelm Meister imitation, albeit a failed one.

Yet the only full-length study of the novel-a Berlin dissertation from 1914-concludes (I think correctly) that the novel has less to do with Wilhelm Meister than with Richardson, and specifically with Sir Charles 
Grandison, from which several features appear to have been imported. As Wolzogen later recalled, Schiller often joked that people would always be able to guess she and her sister were of the generation that had grown up with Grandison. (Indeed, Richardson's last novel, often still regarded critically as his weakest, may well have exercised a more lasting influence than the feminocentric plots of his first two works on Continental female authors.) Even more suggestive is the fact that Agnes von Lilien also displays a striking similarity to the English novelist Frances Burney's Evelina, published twenty years earlier. ${ }^{4}$ Whether Wolzogen had actually read Evelina is not ascertainable-and perhaps not the main issue. But what points of reference literary historians select to establish the framework within which they position a work, whether those focal points consist of another text (Wilhelm Meister), authors (Goethe and Schiller), genre (the bildungsroman), "school" (Weimar classicism), or a single dominant language (German), is of crucial importance. The application of these categories to figures who, like Wolzogen, are doubly marginalized as female and as producers of "ephemeral" popular literature makes it all too easy to assign them a place as imitators, trivializers, or at best popularizers of a hegemonic national literary tradition.

Currently Wolzogen, like many of her English and a few of her German female contemporaries, is receiving renewed attention; a planned edition of her complete works has already yielded a reprint of Agnes, and will eventually encompass her second novel, uncollected Nachlaß, and journals. Such editorial undertakings make research and teaching substantially easier; but they do not guarantee that the same old critical categories will not be applied to the newly available text. In his Afterword, for instance, the editor of the recent Agnes reprint recurs to an old lament, proclaiming regretfully that Wolzogen's novel is indeed "no Wilhelm Meister. Whereas there all parts of the work enter into a connection with each other, here [in Agnes] clear discrepancies exist." Two intervening centuries of German literary criticism have not loosened the hold of the classicist aesthetics by which a work is judged, and in this case inevitably found wanting, according to the effect it produces of internal coherence and closure. The editor is also bothered

"Stephan Brock, Caroline von Wolzogens "Agnes von Lilien" (1798): Ein Beitrag zur Geschichte des Frauenromans (Berlin: H. Blanke's Buckdruckerei, 1914). As Brock notes, both Agnes von Lilien and Evelina feature supposedly orphaned heroines, raised by kindly pastors in the country, who are abruptly moved into an unsettling urban milieu where, in the course of successfully undergoing a string of compromising personal embarrassments, they are reunited with their parents and emerge vindicated under the enamored but critical scrutiny of the older noblemen who finally become their husbands. 
by how the destiny of Wolzogen's female protagonist "is constantly being forced in new directions by external, often insignificant circumstances"; he caps his critique by approvingly citing Goethe's own expressed irritation with the jumpiness and the abrupt rhythm of the novel's exposition, "which don't allow one a moment to arrive at a feeling of ease" ("lassen einen nicht einen Augenblick zur Behaglichkeit kommen"). ${ }^{5}$

Goethe's dissatisfaction with the lack of readerly Behaglichkeit-literally, "comfort" or "coziness" - the novel generates may ring familiar to readers of Frances Burney, Charlotte Smith, Ann Radcliffe, Benedikte Naubert, and other gothic-influenced female novelists of the 1790s. Compared to Burney's later female protagonists, or the spectacularly persecuted medieval heroines of Naubert's historical fiction, Wolzogen's Agnes leads an idyllic life. But the "female difficulties" of all these protagonists, reflected in the dis-ease, discrepancies, and tension generated by their stories, originate precisely in their female vulnerability to the power of "insignificant circumstances" and misleading appearances to determine the structure and rhythm of their existence. Agnes's horror-struck exclamation when she must "cloak the truth in silence, must become the victim of the unfortunate conjunction of circumstances which sully the purity of my character in his eyes!' (1:292) could be taken, almost word for word, from countless novels by Wolzogen's female contemporaries, both English and German.

Likewise, if these feminocentric novels do display the surfeit of abrupt, even "unbelievable" plot turns for which they are criticized, these features represent a structural embodiment of the young, dependent single woman's subservient positioning vis-à-vis all the people in her world who are able to assert authority over her and who can accordingly subject her to peremptory impositions and transitions. Female protagonists simply cannot extricate themselves from the nexus of the nuclear family as easily as the picaro and the roaming protagonists of the male bildungsroman. Even the many heroines supposedly orphaned in infancy find their dead parents exercising a baleful influence beyond the grave, or, if long-lost mothers and fathers should miraculously pop back up, they bring with them a new set of conflicting claims of affection and authority. For instance, Wolzogen's Agnes, like the later protagonist of Burney's Female Difficulties, is faced with having to purchase the freedom of an imprisoned, politically persecuted father with an unwanted marriage. Thus, her father's apparently disinterested

${ }^{5}$ Caroline von Wolzogen, Agnes von Lilien, in Gesammelte Schriften I, ed. Peter Boerner (Hildesheim: Georg Olms, 1988), 2:402-3; all further references are cited in the text. 
decision to have Agnes's education concentrate on the inculcation of a stoically self-reliant inner serenity ultimately serves his needs as much as her own. "My daughter should be able to achieve through her self all that constitutes the true worth of life, and neither the enjoyment nor the want of the uncertain endowments of happiness should be capable of destroying the balance of her finer being" (2:132). Gleichgewicht, Gleichmuth, Harmonie-balance, equanimity, harmony: the frequency with which such words are invoked like a mantra by Wolzogen's own protagonist and other beset heroines created by her fellow female novelists leaves it unclear whether these all-encompassing terms encode a feminine ideal of obedient docility or one of resolute independence-or the psychological double bind of living up to both ideals simultaneously. ${ }^{6}$

The questions Wolzogen's Agnes von Lilien raises, as well as the reception her novel encountered, make it an unusually apt example of the issues involved in a comparativist analysis of eighteenth-century women's fiction. Viewing the novel in a comparativist context does not merely widen the traditional interpretive parameters, but, more important, it focuses analytic attention on exactly what the text does, in its own terms, rather than on what it fails to do. By the same token, structural and stylistic "discrepancies" and readerly "discomfort," rather than being summarily condemned or explained away, need to be employed as valuable clues to the desires as well as the anxieties women novelists of the era were activating and assuaging. After all, the enthusiastic consumption and production of fiction by women has been a constant factor of the European literary market for almost three centuries. As Lillian S. Robinson observes: "Feminists are not in agreement as to whether domestic and sentimental fiction, the female Gothic, the women's sensational novel functioned as instruments of expression, repression, or subversion, but they have successfully revived interest in the question as a legitimate cultural issue. It is no longer automatically assumed that literature addressed to the mass female audience is necessarily bad because it is sentimental, or for that matter sentimental because it is addressed to that audience. ${ }^{\prime 7}$

\footnotetext{
${ }^{6}$ For other approaches to Wolzogen's novels, see Christa Bürger, Leben Schreiben: Die Klassik, die Romantik, und der Ort der Frauen (Stuttgart: Metzler, 1990), 161-63; and Antonie Schweitzer and Simone Sitte, "Tugend-Opfer-Rebellion: Zum Bild der Frau im weiblichen Erzeihungs-und Bildungsroman," in Frauen Literatur Geschichte: Schreibende Frauen vom Mittelalter bis zur Gegenwart, ed. Hiltrud Gnüg und Renate Möhrmann (Stuttgart: Metzler, 1985), 144-65. For a superb consideration of why more German women of Wolzogen's generation did not write, see Ulrike Prokop, “Die Einsamkeit der Imagination. Geschlechterkonflikt und literarische Produktion um 1770," in Deutsche Literatur von Frauen, ed. Gisela Brinkler-Gabler (Munich: C. H. Beck, 1988), 1:325-65.

${ }^{7}$ Lillian S. Robinson, "Treason Our Text: Feminist Challenges to the Literary Canon,"
} 
The impact of feminist criticism has by now become undeniable within German as well as English eighteenth-century studies, although it infiltrated the former field more slowly, and more through the efforts of marginalized scholars. When attention is paid to the German women writing during the "Goethezeit" it still tends to be directed to traditionally recognized figures such as Rahel Varnhagen, Caroline SchlegelSchelling, and Bettina von Arnim, whose oeuvres are to a large extent epistolary or outside the category of popular fiction. German literature also had its Sarah Fieldings, its Ann Radcliffes, its Frances Burneys and Mrs. Inchbalds. ${ }^{8}$ Their oeuvres, however, have received much less attention than those of their English female contemporaries, to the extent that they have been critically relegated to what, in German terminology, is labeled, with telling severity, Trivialliteratur-literally, "trivial literature," although the word would more likely be translated as "mass literature" in English. Indeed, it is increasingly apparent that the "highlow" dichotomization of literature itself has a strong gendered component and that the female producers and consumers of "mass" or "middle-brow" culture have played a major role during the last two centuries in constituting the often unnamed abjected "Other" of neoclassicist, Romantic, and modernist aesthetic practice. ${ }^{9}$

The sociology of literature, and especially the examination of critical categories applicable to mass literature, popular culture, and even "kitsch," has been one of the strong points of postwar German literary studies influenced by the Frankfurt school, the reader-response theory of Wolfgang Iser, and the Konstanz school's reception theory. Yet, paradoxically, even as such scholarship served to legitimate the study of

in The New Feminist Criticism: Essays on Women, Literature, and Theory, ed. Elaine Showalter (New York: Pantheon, 1985), 116.

${ }^{8}$ See the introduction to Ruth-Ellen B. Joeres and Mary Jo Maynes, eds., German Women in the Eighteenth and Nineteenth Centuries: New Studies in Social and Literary History (Bloomington: Indiana University Press, 1985), ix-x; and also Katherine Goodman and Edith Waldstein, eds., In the Shadow of Olympus: German Women Writers around 1800 (Albany: SUNY Press, 1992), 1-29. The two major studies of German eighteenth-century women's novels are Christine Touaillon, Der deutsche Frauenroman im 18. Jahrhundert (1979; rpt. Vienna: Wilhelm Braumüller, 1919); and Helga Meise's indispensable Die Unschuld und die Schrift: Deutsche Frauenromane im 18. Jahrhundert (Berlin: Guttandin \& Hoppe, 1983). See also Eva Walter "Schrieb oft, von Mägde Arbeit müde": Lebenszusammenhänge deutscher Schriftstellerinnen um 1800-Schritte zur bürgerlichen Weiblichkeit (Düsseldorf: SchwannBagel, 1985); and Jeannine Blackwell and Susanne Zantop, eds., Bitter Healing: German Women Writers from 1700 to 1830 (Lincoln: University of Nebraska Press, 1990).

${ }^{9}$ Andreas Huyssen, "Mass Culture as Woman: Modernism's Other," in Studies in Entertainment: Critical Approaches to Mass Culture, ed. Tania Modleski (Bloomington: Indiana University Press, 1986), 188-207. See also Marion Beaujean, Der Trivialroman in der zweiten Hälfte des 18. Jahrhunderts: Die Ursprünge der modernen Unterhaltungsliteratur (Bonn: Bouvier, 1964); and Christa Bürger, Peter Bürger, and Jochen Schulte-Sasse, eds., Zur Dichotimisierung von hoher und niederer Literatur (Frankfurt am Main: Suhrkamp, 1982). 
popular literature and culture, at the same time the key concept of the Culture Industry discouraged an examination of the artifacts of popular culture on their own terms, and for their own aesthetic merits. ${ }^{10}$ As Tania Modleski states: "It is one of the great ironies in the development of mass-culture theory that the people who were first responsible for pointing out the importance of mass art simultaneously provided the justification for slighting it." ${ }^{\prime 11}$ This situation has contributed to the occlusion of women's writing as an object of scholarly interest, especially in German studies, since within the canonical outlines of German literature such writing is even more likely to be located outside the boundaries of the high or "autonomous" art which has proved so influential in propagating and institutionalizing the ideology of the ewig Weiblich, the Eternal Feminine.

But, whatever culturally specific version of the ewig Weiblich German and English women lived with, the conflict between the overwhelming public presence of a feminine ideal and the typical quotidian female difficulties left an indelible mark on the novels they produced. For even when they turned to a species of fiction that claimed (and was accorded) limited literary authority, female novelists were necessarily confronted with the contradiction inherent in their own "unfeminine" entry into a masculine public sphere, and driven to acknowledge, however delicately or deviously, the gap thus opened up between public ideal and personal conduct.

The last decades of the eighteenth century, together with the first twenty years of the nineteenth, witnessed not only the emergence of a new liberal discourse of gender, but also the intersection of this discourse with other debates shaping the public sphere of politics. The 1790 mark the high point of the theoretical discussion of what role, if any, women might play in the ongoing production of communal history; essays published during the decade by Talleyrand and Condorcet in France, by Mary Wollstonecraft and Catherine Macaulay in England, and by Theodor von Hippel in Prussia all argue for an extension of certain male prerogatives to select females. ${ }^{12}$ The same period also witnessed the consolidation of the ideology of idealized femininity, a de-

${ }^{10}$ See Lillian S. Robinson, Sex, Class, and Culture (Bloomington: Indiana University Press, 1978), 69-94; Fredric Jameson, "Verdinglichung und Utopie in der Massenkultur," in Bürger et al., Zur Dichotimisierung von hoher und niederer Literatur, 108-41; and Tania Modleski, Loving with a Vengeance: Mass-Produced Fantasies for Women (New York: Methuen, 1984).

${ }^{11}$ Modleski, Loving with a Vengeance, 26.

${ }^{12}$ See Susan Bell and Karen M. Offen, eds., Women, the Family, and Freedom: The Debate in Documents, vol. 1, 1750-188o (Stanford: Stanford University Press, 1983). 
velopment that served to recontain the nascent emancipatory impulses unleashed by the Enlightenment and the French Revolution, and to push public reconsideration of "the woman question" back by over half a century. During the roughly forty years in which the "proper lady" worked her way up to the "Angel of the House" and the "perfektes Frauenzimmerchen" of mid-eighteenth-century conduct manuals was apotheosized into the "Priesterin und Lichtbringerin" of the German Romantics, the various discourses on gender within medicine, law, psychology, and aesthetics managed to restabilize the potentially threatening force of the feminine by conceding it the privileged roles of domestic organizer and cultural consumer within the private sphere. As Mary Poovey has summarized: "The ultimate effect of the revolutionary decades was to intensify the paradoxes already inherent in propriety.... As a consequence, the women who grew up during these decades, or who immediately inherited their ideological legacy, experienced a particularly intense version of the contradictions we have been examining. ${ }^{\prime \prime 13}$

Nevertheless, in spite of this abandonment of overt emancipatory agitation, it was also between roughly 1760 and 1810 that women in both Germany and England started entering the public realm of publishing to an unheard-of extent-as poets, polemicists, dramatists, and above all novelists. J. M. S. Tompkins estimates that a third to a half of the novels that stocked the English circulating libraries during this era were written by women-although that is difficult to verify, given that precisely this class of ephemeral production was most quickly consigned to historical oblivion, and that female authors seem to have been

\footnotetext{
${ }^{13}$ Mary Poovey, The Proper Lady and the Woman Writer: Ideology as Style in the Works of Mary Wollstonecraft, Mary Shelley, and Jane Austen (Chicago: University of Chicago Press, 1984), 30. Two other considerations of changing conceptualizations of gender roles at the end of the century in relation to literature are Barbara Becker-Cantarino, "Priesterin und Lichtbringerin: Zur Ideologie des weiblichen Charakters in der Frühromantik," in Die Frau als Heldin und Autorin, ed. Wolfgang Paulsen (Munich: Fink, 1979), 111-24; and Volker Hoffmann, "Elisa und Robert oder das Weib und der Mann, wie sie sein sollten: Anmerkungen zur Geschlechtercharakteristik der Goethezeit," in Klassik und Moderne: Die Weimarer Klassik als historisches Ereignis und Herausforderung im kulturgeschichtlichen Prozeß, ed. Jörg Schönert and Karl Richter (Stuttgart: Metzler, 1983), 80-97. Relevant secondary sources on social history include Lawrence Stone, The Family, Sex, and Marriage in England, 1500-180o (London: Weidenfeld \& Nicolson, 1977); Roy Porter, English Society in the Eighteenth Century (Harmondsworth: Penguin, 1982); Heidi Rosenbaum, Formen der Familie: Untersuchungen zum Zusammenhang von Familienverhältnissen, Sozialstruktur und sozialem Wandel in der deutschen Gesellschaft des 19. Jahrhunderts (Frankfurt am Main: Suhrkamp, 1982); Barbara Becker-Cantorino, Der lange Weg zur Mündigkeit: Frau und Literatur, 15001800 (Stuttgart: Metzler, 1987); and Karin Hausen, "Die Polarisierung der 'Geschlechtscharaktere' -Eine Spiegelung der Dissoziation von Erwerbs-und Familienleben," in Seminar: Familie und Gesellschaftsstruktur, ed. Heidi Rosenbaum (Franfurt am Main: Suhrkamp, 1983), 165-92.
} 
especially inclined to anonymous publication. Elizabeth Friedrichs lists over two hundred female authors writing in German during the century, but again, many of their works have apparently disappeared, known only by their titles. ${ }^{14}$

The novels by English and German women, of course, still must represent a limited percentage of the total novelistic output between 1770 and 1810, a period in which the rate of production jumped astronomically. But, even while reviewers sneered at yet another febrile product of a female pen, or damned it with faint praise, the public at large still voted with their pocketbooks, encouraging publishers to worry less about the sex of a work's author than its salability, and encouraging even more women to venture into this field. Hence, despite the dictates of an internally contradictory and increasingly rigorous ideology of femininity, on the most basic economic level the market was undeniably granting to select women precisely what the moralists admonished them to renounce: the license to indulge in their own powers of imagination, and a taste for financial self-sufficiency. Even as polemicists on both sides of the Channel were recurring ad nauseam to Rousseau's observation that the best woman is exactly the one who is not talked about at all, who consists of a kind of public tabula rasa, a historical nonentity, publishers and readers were implicitly encouraging the "talk" of and about women in print, rewarding female authors as never before for their personal histories or fabulated accounts of spectacular female lives for the delectation of the public.

This development ensured that the female novelist, together with other varieties of the Lady of Letters, would become an increasingly visible, if not always approved, type in the course of the century. Female authors were not, of course, a totally unknown phenomenon before the onset of the era. In England prior to 1730 Aphra Behn, Delariviere Manley, and the novelist and journalist Eliza Haywood had all supported themselves by writing-but at the price of literary and personal notoriety. And no German woman produced a first-class fictional hit until 1771, when Sophie von La Roche's Geschichte des Fräuleins von Sternheim, which was edited by Wieland and praised by Goethe, ushered in a new era of fictional production in German by women. ${ }^{15}$

${ }^{14} \mathrm{~J}$. M. S. Tompkins, The Popular Novel in England, 1770-1800 (London: Methuen, 1932), 119-20; and Elizabeth Friedrichs, Lexikon der deutschsprachigen Schriftstellerinnen des 18. und 19. Jahrhunderts (Stuttgart: Metzler, 1983). See also Katherine M. Rogers, Feminism in Eighteenth-Century England (Urbana: University of Illinois Press, 1982), esp. appendix, and Meise, Die Unschuld und die Schrift, 253-59.

${ }^{15}$ See Monika Nenon, Autorschaft und Frauenbildung: Das Beispiel Sophie von La Roche (Würzburg: Königshausen \& Neumann, 1988). 
Several German women who published fiction during the three decades that followed had some personal connection with one or more prominent literary men: Caroline von Wolzogen; Sophie Mereau (later Brentano's wife); Georg Forster's former wife, Therese Huber; the dramatist Kotzebue's sister, Amalie Ludecus; Friedrich Schlegel's wife, Dorothea (the daughter of Moses Mendelssohn); Friederike Helene Unger, the wife of the influential Berlin publisher and friend of Nicolai and Jacobi; and the poet August Bürger's wife, Elisa Hahn (whose scandalous divorce from him made a bigger impression on the German public than her subsequent novels). Others broke into publishing without the benefit of well-placed male connections and, in some cases, abandoned it just as unobtrusively. Karoline von Wobeser, for example, having produced one of the sensational successes of the 179os, Elisa, oder das Weib wie es sein soll (Elisa, or woman as she should be), a didactic novel which insists that the truly good woman lives for home and family, at least had the grace to take her own advice; resisting the temptations of success, she disappeared back into anonymity, never to be heard from again. And Benedikte Naubert, who turned out an average of two full-length works a year between 1787 and 1802, thus managing to dominate the market for historical fiction in Germany by virtue of not only the quality but also the quantity of her production, was able to preserve her anonymity until 1815 .

Although some women writers were free from the financial pressure to write, many others found themselves motivated to write for profit only during certain intervals of their lives. In both German-speaking Europe and England, a certain pattern of women who looked to their pens to support themselves and their dependents in the wake of marital abandonment, separation, or widowhood is evident (Charlotte Smith and Mary Ann Radcliffe, left with ten and eight children, respectively, to support; Anne Masterman Skinn, Eliza Fenwick, Elisa Hahn, Isabella Wallenrodt, Caroline Augusta Fischer). During the late eighteenth century, after all, the field of economic options for female self-support actually narrowed; likewise, there is evidence that, at least in England, the wealth accessible to women in the forms of property settlements, inheritances, and jointures also decreased. For some, such as Frances Burney, Dorothea Schlegel, and the older Sophie von La Roche, the income generated by their writing, while it did not spell the difference between destitution and comfort, was still a welcome addition. Others, such as Huber and Mereau Brentano, became full-time, self-supporting literary professionals, eking out a precarious but independent living from the combined activities of novel writing, journalism, editing, and translating. (Translating poses a particularly interesting case, since it 
provided women with a way into the literary market that offered them training in their craft, as well as exposure to another national literature.)

In England the professional involvement of women such as Huber and Mereau Brentano is paralleled by the industriousness of novelwriting journalists such as Mary Wollstonecraft and Mary Hays, and the inexhaustible Charlotte Smith. Of course, in England female novelists made their mark earlier than in German-speaking Europe; the 1760 s had been punctuated by the appearance of works by women writers, some patterned on Richardsonian precedents, and sometimes written by women personally acquainted with Richardson, such as Elizabeth Griffith and Charlotte Lennox. Sophia and Harriet Lee, as well as Clara Reeve, were all writing in the 1780s; Charlotte Smith's career actually began in that decade; and Frances Burney's had been inaugurated in the 1770s, with the runaway success of Evelina.

But it was the 1790s, a decade marked in England by social unrest and political agitation, which was dominated by the spectacular success of the gothic novelist Ann Radcliffe and by the literary and publicistic activities of the Jacobin writers, including a remarkable number of women-not only Wollstonecraft and Hays, who were to bear the brunt of the public malice directed toward such radicals in petticoats, but also Elizabeth Inchbald, Mary Robinson, Eliza Fenwick, and Amelia Opie. Some of these women, such as Opie, were later to disassociate themselves from the politics and personalities of the Jacobin circle, while yet other women writing around the turn of the century, including the satirist Elizabeth Hamilton and the ever-formidable Hannah More, strove to combat what they viewed as the especially noxious influence of their liberal literary contemporaries.

And yet, despite the frenetic political agitation and sometimes rabid personal animosities that characterized English literary life during this decade, dichotomous categories such as "freethinker" versus "didactic moralist" or "liberal" versus "conservative" really say less about the position of these English women novelists than the fact that all of them, whatever their overt political stance, were resorting to the medium of the published word to articulate their perspectives on events taking place in the realm of public history. Nothing illustrates the importance of this factor more clearly than the writings of Hannah More. Authorship was certainly not one of the attributes included in More's conception of the ideal female, and yet she apparently did not dwell on the ironic contradiction evident between her rigorous strictures and the example of her own successful, thoroughly professional career. More was not unique in this respect, for she provides just one illustration of what Jane Spencer views as "a trend very general in the later years of the 
century: women novelists were carving a public niche for themselves by recommending a private, domestic life for their heroines." ${ }^{\prime 16}$

This disjunction between market-generated opportunities and gendered roles and expectations was only one of the components of female authorship in England and German-speaking Europe during the late eighteenth century. Women were caught in other, homologous contradictions in almost every sphere of their experience-on the levels of education, of marriage, of domestic organization and child rearing, of social interaction outside the home, of their cultural positioning vis-àvis literary tradition, and of political involvement and affiliation. These conflicts are reflected in the works (as well as the careers) of English and German female novelists of the era, but in the highly mediated form that the novel permits. On the one hand, the genre of the novel may have granted eighteenth-century authors an unprecedented license to examine and represent the conditions and the unfolding panorama of contemporary life. On the other hand, the fascination this newly opened up literary territory exercised on the popular imagination still by no means legitimated unsupervised narrative and thematic free play within its boundaries. It is indeed possible to view the novel as a form fundamentally connected to the tropes and themes of transgression, the transgression that ensues on a variety of levels when the modern self of Western subjectivity, in encountering communal forces that threaten its prerogatives, discovers its autonomy and alienation. ${ }^{17}$ But visions of the novel as a literary carrier of ideologically destabilizing energy have to be balanced by the admission that the attention paid within the novel to the phenomenon of the self contemplating itself is overdetermined by the limited repertoire of narrative models available in the late eighteenth century for the fictional inscription of individual destiny. This in turn ensured that the novel, by its very popularity if nothing else, itself functioned as a vehicle for the recontainment, the proper socializationin short, the supervisory policing-of the reading and writing subject. Indeed, as Friedrich Kittler has shown, a semiotechnology of reading and writing which emerged in the eighteenth century in tandem with the addictive habit of novel consumption served to anchor the interiority of the literate individual precisely in his or her ability to overlook

\footnotetext{
${ }^{16}$ On More, see Rogers, Feminism in Eighteenth-Century England, 209-13; and Mitzi Myers, "Reform or Ruin: 'A Revolution in Female Manners,' "' in Studies in Eighteenth-Century Culture, ed. Roseann Runte (Madison: University of Wisconsin Press, 1979). Spencer, Rise of the Woman Novelist, 20.

${ }^{17}$ See Tony Tanner, Adultery in the Novel: Contract and Transgression (Baltimore: Johns Hopkins University Press, 1979); also Peter Stallybrass and Allon White, The Politics and Poetics of Transgression (Ithaca: Cornell University Press, 1986).
} 
the materiality of the "letter's" inscriptive medium in order to internalize and personalize the "spirit" of its message all the more thoroughly. Likewise, Nancy Armstrong has linked the eighteenth-century novel of conjugality and domesticity to the related form of the conduct manual, positing that such fiction carried on, in its own terms, the more overtly didactic handbooks' mission of redefining and reorganizing middle-class private life around gender differentiations. ${ }^{18}$

Furthermore, it seems logical that the fate of the female self, which was arousing so much novelistic interest from the middle of the eighteenth century onward, would be particularly affected by the conflict between self-exploration and self-discipline played out in the novelon the levels of individual female authors, female readers, and fictional female protagonists. The weaker sex was, after all, supposed to be more in need of helpful supervision, far more vulnerable to being hastily judged on appearance, however unjustly. This emphasis on the vigilant monitoring of female behavior in turn not only intensified the selfconsciousness of women writers, heightening the conflict foregrounded in the novel between the development of a certain self-conception and others' possible misconceptions, but also loaded the dice in favor of conventionally admonitory representations of female fate.

Most English and German women novelists seem to have worked with the generic resources at hand, utilizing the fictional tools they found to highlight certain pragmatic difficulties inherent in contemporary female existence, to delineate the contours of an acceptably selfconscious female subject, and to gesture toward experiences not depicted in detail on account of decorum, conventions, or lack of exposure. This description may run the risk of appearing to domesticate or diminish the achievements of these writers by presenting them as examples of the art of the miniature, a matter of unobtrusive permutations. But then Walter Benjamin has noted how dangerous "the domesticated passions" - of the collector, the copyist, the obsessional correspondent, and other artists of the appropriated detail-can be. ${ }^{19}$ And, by extension, perhaps most literary genres, like other discourses, are in actuality transformed not by abrupt, dramatic epistemological breaks, as effected by the experiments of a handful of radical aesthetic innovators, but rather by means of the gradual, micro-level widening

${ }^{18}$ Friedrich Kittler, Discourse Networks, 1800-1900 (Stanford: Stanford University Press, 1990). Nancy Armstrong, Desire and Domestic Fiction: A Political History of the Novel (Oxford: Oxford University Press, 1987).

${ }^{19}$ Walter Benjamin, "Eduard Fuchs: Collector and Historian," in The Essential Frankfurt School Reader, ed. Andrew Arato and Eike Gebhardt (New York: Urizen, 1978), 241. 
or shifting of the total range of "enunciatory possibilities." ${ }^{20}$ As Dana Polan suggests: "Rather than understanding formal innovation to be a deconstruction of dominant ideology, we might want to deconstruct the whole underlying philosophy of a critical practice that places innovation and dominance in opposition, that understands mass culture to be an ideological form that is most effective when it is formally and thematically most simple."'21

Furthermore, to categorize these writers in terms of an either/or schema-either formally conservative or pointedly experimental, either docile imitators of given "masculine" fictional constructs or exponents of a consciously "female" tradition or Frauenliteratur-entails ignoring complexities that arise when members of a culturally marginal group encounter a dominant literary heritage, particularly at a historical juncture where a recognizably feminist or proto-feminist political discourse is just beginning to emerge. For this situation another interactive model is required, one that acknowledges the fact that women writing "are not, then, inside and outside of the male tradition; they are inside two traditions simultaneously, 'undercurrents,' in Ellen Moers's metaphor, of the mainstream.."22 Or, to use Sigrid Weigel's favored specular metaphor of "der schielende Blick" (which denotes either an oblique sidelong gaze or, simply, a cross-eyed gaze), feminist scholars must proceed on the assumption that female writers since the end of the eighteenth century have viewed themselves and their female readers through the prescribed lens of internalized phallocentric cultural constructions of "the feminine," producing a necessarily split, doubled, or wavering focus. ${ }^{23}$ At any rate, whether the conceptual model is to be specular or hydraulic (crossed eyes or cross-currents), both suggest that a constant factor of women's literary culture, whatever the language, will consist of an inconsistency that results from a constitutive ambivalence.

This brief outline of the conditions and contradictions pertaining to female authorship in the late eighteenth century suggests that an investigation of novels written during that period by women could be enriched not just by crossing the demarcated disciplinary boundaries of various national literatures, but also by drawing simultaneously on

\footnotetext{
${ }^{20}$ See Michel Foucault, "The Archaeology of Knowledge" and "The Discourse on Language," trans. A. M. Sheridan Smith (New York: Harper \& Row, 1972), 166-77.

${ }^{21}$ See Dana Polan, "Brief Encounters: Mass Culture and the Evacuation of Sense," in Modleski, Studies in Entertainment, 170.

${ }^{22}$ Elaine Showalter, "Feminist Criticism in the Wilderness," in Writing and Sexual Difference, ed. Elizabeth Abel (Chicago: University of Chicago Press, 1983), 32.

${ }^{23}$ Sigrid Weigel, "Der schielende Blick: Thesen zur Geschichte weiblicher Schreibpraxis," in Inge Stephan and Sigrid Weigel, Die verborgene Frau: Sechs Beiträge zu einer feministischen Literaturwissenschaft (Berlin: Argument, 1983), 83-137.
} 
several other relevant fields of inquiry: the sociology of publication and reading practices; pedagogy; philosophy; personal biography (when possible); the social history of family, childhood, and adolescence; and the development of the scientific, medical, and proto-psychiatric discourses which, as Thomas Laqueur has shown, have constructed gender and steered representation in the process of "making sex." Comparative literature, after all, in spite of its traditional methodologies and sometimes circumscribed self-definition, currently appears to offer one site within the institution of the university humanities where this kind of boundary-crossing borderwork is more likely to be greeted with tacit toleration, if not open encouragement. But whatever approach is deployed, and however pluralistic it may be, it is absolutely indispensable, in this case, that it be articulated with the detailed close textual analysis of the novels themselves. For in the late eighteenth century the novel form was, in spite of the formal precedents furnished by Richardson and Fielding in England and Gellert in Germany, in an amorphous phase and able to encompass a looseness, digressiveness, and (in spite of the bounds of decorum) expansiveness of both scope and tone. In this respect the tight formal symmetry of Jane Austen's novels is not necessarily representative of the work the majority of her female contemporaries were producing, for whom discursiveness itself seems to be one noticeable side effect of the complex discursive conjuncture to which they are responding. It is therefore all the more necessary to approach these texts, often cursorily dealt with or accorded a brief plot and thematic summary in the secondary literature, as complete, complicated artifacts. Episodes, subplots, and individual characters need to be viewed within the structure of the work as a whole, for it is only in the context of the whole that the significance, indeterminacies, and revealing "discrepancies" embedded in discrete narrative elements may become fully visible.

In fact, many of the texts themselves are riddled with structural oddities, narrative blind spots and dead ends, and ideological inconsistencies-notably the inconsistency of a "happy ending" (usually matrimony) hastily or limply appended to a narrative to smooth out belatedly the rocky stretches of resentment, rebellion, apprehension, and misapprehension that have impeded the heroine's recognition and assumption of her proper, preordained "female destiny." As Helga Meise has noted: "The 'chaos' of writing, the attempt to anchor ironies and irritations in writing itself, pulls the 'literarization of female destiny' ... into visibility, even when it is considered as an aberration. Writing is therefore a particularly dangerous means of propagating ' $\mathrm{fe}$ male destiny,' simultaneously miming it and unmasking it, not taking 
it seriously and, at the same time, seeking out yet other adventures in its name." 24 Janet Todd, too, has noted how the very act of writing could function to widen, if not completely spring, the limits of the eighteenth-century "sentimental female image": "In sentimental literature women could complain obliquely, refashion the structures of power they inhabited, recreate their own images, and reform men. Through writing, repression turned into expression, and the passivity of the ideal was modified by a creative act of literature that could not be passive. ${ }^{\prime 25}$

Given such significatory cross-currents, it is essential to admit once again that these texts, precisely inasmuch as they encode the contradictions operating between material conditions, ideological formations, and what Raymond Williams has called the mediating "structures of feeling," simultaneously reinforce and resist the era's assumptions about the role of women and the woman writer. For most of these novels are neither brazenly rebellious nor merely smugly sanctimonious. Instead, they can be both by turns, since many are played out within a shifting, unstable interpretational terrain in which small acts take on troublingly double-edged connotations, where "resignation" may be a cipher for resentment, where properly feminine submission becomes, in hindsight, blind gullibility, and where silence can provide either a shield for duplicity or the only way of remaining honest. These textual half-tones make such works especially appropriate objects of the type of "grey, meticulous, and patiently documentary" analysis Michel Foucault called "genealogical," which "operates on a field of entangled and confused parchments, on documents that have been scratched over and recopied many times." 26

As Foucault emphasizes elsewhere: "We must not imagine a world of discourse divided between the dominant discourse and the dominated one; but as a multiplicity of discursive elements that can come into play in various strategies.... Discourses are not once and for all subservient to power or raised up against it, any more than silences are.' ${ }^{27}$ Furthermore, as Biddy Martin has commented: "It is neither an

${ }^{24}$ Meise, Die Unschuld und die Schrift, 206.

${ }^{25}$ Janet Todd, ed., The Dictionary of British and American Women Writers, 1660-1800 (Totowa, N.J.: Rowman \& Allanheld, 1985), 19-20.

${ }^{26}$ Michel Foucault, "Nietzsche, Genealogy, History," in Language, Counter-Memory, Practice: Selected Essays and Interviews by Michel Foucault, ed. Donald F. Bouchard (Ithaca: Cornell University Press, 1977), 139. For a useful application of Foucault, see the introduction to Katherine Goodman, Dis/Closures: Women's Autobiography in Germany between 1790 and 1914 (New York: Lang, 1986).

${ }^{27}$ Michel Foucault, The History of Sexuality (New York: Random House, 1980), 1:100101. 
absolute silence nor an absolute exclusion which characterizes women's situation in.western culture and perpetuates our oppression, but rather a constitutive silence and an assimilated speech." ${ }^{\prime 28}$ This makes it almost impossible to describe their social positioning in any context in terms of unrelieved oppression or total exclusion. But the last four decades of the eighteenth century can at least be identified as a turning point, if in a limited sense, inasmuch as a group of English and German women-admittedly almost all middle to upper class and relatively well educated-exploited a particular cross-national conjuncture of economic, aesthetic, and discursive developments to appropriate one field of literary articulation, the novel. If many of these writers' works are marked by the unresolved triangular tension between a traditionally enjoined female silence, a decorously assimilated speech, and a certain privilege of expression, then that ambivalence should not be taken as an indication of such novels' triviality or timidity, or used to reinforce criteria by which they become, at best, the evolutionary forerunners of more overtly critical "feminist" texts, or of a unidirectionally plotted Female Great Tradition.

The comparative analysis of the late eighteenth-century women's novel can serve, in fact, as a test case to demonstrate how individual works by women writers can be productively approached not only visà-vis their adherence to or divergence from discrete literary traditions (whether defined by language, school, or linear development), but also as part of the formative yet fluid matrix provided by a cross-national continuum of shared female experiences and productive "difficulties." If this, in turn, seems to call for simultaneously negotiating a dangerous number of critical acts of mediation and translation-between two languages, two literatures, two bodies of critical commentary, between social history and literary history, between "popular" and "high" artsuch mediation has been the traditionally accorded task, risk, and, above all, pleasure of comparative literature within the institution of literary studies.

\footnotetext{
${ }^{28}$ Biddy Martin, "Feminism, Criticism, and Foucault" in New German Critique 27 (Fall 1982): 18 .
} 